\title{
Cellular aspects of fuel mobilization and selection in white adipocytes
}

\author{
BY MAX LAFONTAN AND DOMINIQUE LANGIN \\ Unité INSERM 317, Institut Louis Bugnard, Faculté de Médecine, Université Paul Sabatier, \\ CHU Rangueil, Bât. L3, 31054 Toulouse Cedex, France
}

\section{Aspects cellulaires de la mobilisation et sélection des substrats énergétiques de l'adipocytes blancs}

\begin{abstract}
RÉSUMÉ
La plus grande partie (95\%) de tous les triacylglycérols du corps est située dans les dépôts de graisse blanche, d'où l'importance du tissu adipeux dans la régulation de l'équilibre de l'énergie. La mobilisation des graisses (libération d'acides gras non estérifiés (AGNE) et de glycérol du tissu adipeux) joue un rôle majeur dans la régulation de tout le métabolisme des lipides (Coppack et al. 1994). La lipase sensible aux hormones (EC 3.1.1.3; LHS) est responsable de l'hydrolyse des triacylglycérols stockés dans les cellules adipeuses. Son contrôle équilibré par des hormones cataboliques et anaboliques et des neurotransmetteurs fournit à d'autres organes métaboliquement actifs un apport vital en substrats énergétiques tels que les AGNE, et en précurseurs gluconéogéniques tels que le glycérol. Les récents progrès, au niveau de la cellule, sur la nature et le rôle des principales voies impliquées dans le contrôle de la lipolyse des triacylglycérols de la cellule adipeuse sont présentés. En outre, de nouveaux aspects concernant la sélectivité de la mobilisation des AGNE et les mécanismes impliqués dans la mobilisation différentielle des AGNE sur les triacylglycérols de la cellule adipeuse sont également discutés. Une étude récente a démontré que, dans la lipolyse stimulée par hormone in vitro, les AGNE sont plus facilement mobilisés à partir des cellules adipeuses quand ils sont courts et insaturés, et quand les doubles liaisons sont plus proches de l'extrêmité méthyl de la chaîne (Raclot \& Groscolas, 1993). L'élucidation récente de l'organisation du gène de la LHS humaine (Langin et al. 1993) devrait s'avérer utile pour l'étude de la régulation cellulaire de la LHS. Les mécanismes précis qui déterminent le taux de lipolyse des tissus adipeux ne sont pas encore entièrement connus. La LHS est activée par la phosphorylation cAMP-dépendante d'un seul résidu serine (Ser551 dans la LHS humaine). Ce site régulateur est phosphorylé par la protéine kinase dépendante de l'AMPc ( $E C$ 2.7.1.37; kinase A), et cette activation est déclenchée par un grand nombre d'agents stimulant l'adénylyl-cyclase ( $E C$ 4.6.1.1; Lafontan \& Berlan, 1993). Il a été trouvé qu'un autre résidu serine (Ser553 dans la LHS humaine) était un second site de phosphorylation, phosphorylé par la protéine kinase activée par l'AMP 5'. La phosphorylation de ce site basal ne conduit pas à une activation de la LHS, et empêche la phosphorylation du site régulateur par la kinase A. L'importance physiologique de ce site basal est encore inconnue. Les agents antilipolytiques agissent essentiellement par une diminution des niveaux de l'AMPc des adipocytes, soit par une inhibition de l'adénylyl-cyclase par des protéines Gi (adénosine, NPY, la composante $\alpha-2$ adrénergique des catécholamines, PYY, prostaglandine E2), soit par une activation de la phosphodiestérase AMPc-dépendante de l'AMPc (EC 3.1.4.17) inhibée par le
\end{abstract}


GMPcyclique, (comme l'insuline), qui aboutit à une diminution de la phosphorylation et de l'activation de la LHS. L'importance relative des promoteurs et des inhibiteurs de la lipolyse impliqués dans le réglage subtil de l'activité de la LHS et de la disponibilité des AGNE est discutée.

White adipose tissue is the major energy source in animals and humans. A very large part $(95 \%)$ of total body triacylglycerols (TAG) is located in fat stores and TAG are central metabolic substrates. Adipose tissue makes a major contribution to the regulation of lipid metabolism, as it is a site of clearance of postprandial lipaemia through the action of lipoprotein lipase (EC 3.1.1.34; LPL) on chylomicron TAG and an important site of lipolysis where TAG are hydrolysed intracellularly by the hormone-sensitive lipase ( $E C$ 3.1.1.3; HSL), so named because of its responsiveness to catecholamines and insulin. In the post-absorptive state, this enzyme controlling fat cell lipolysis plays a determinant role in whole-body lipid-fuel availability. The mobilization of white-fat-cell TAG provides the body with a vital supply of fuel in the form of fatty acids (FA) and of gluconeogenic precursors in the form of glycerol. Adipose tissue is the major site of production of non-esterified FA (NEFA) and largely determines the plasma NEFA levels. NEFA have been recognized as the main energy source during starvation, various stressful situations (cold exposure, burn injury, surgical trauma etc.), as well as during exercise (Coppack et al. 1994). Plasma NEFA also represent a major source of energy in post-absorptive states because of their high energy content. Some organs such as the heart utilize NEFA almost exclusively to reach their metabolic requirements. FA are also precursors of essential organic molecules (e.g. prostaglandins, leukotrienes and thromboxane) and appear to be involved in the control of gene expression, cell proliferation and immune responses.

White fat cells are well adapted for their two major functions: storage and release of energy. In the postprandial state, surplus energy is assimilated and stored in fat cells in the form of TAG in lipid droplets in the fat cell vacuole. NEFA release is suppressed and adipose tissue LPL, bound to the luminal side of the capillary endothelium, contributes to the clearance of postprandial lipaemia and TAG storage (for reviews, see Bensadoun, 1991; Enerbäck \& Gimble, 1993). The various pathways involved in the lipogenic processes of the fat cell will not be dealt with here (Saggerson, 1985; Frayn et al. 1992). In post-absorptive situations, HSL activation and lipid mobilization predominate and NEFA become available for oxidation. When NEFA availability exceeds total oxidation capabilities, excess NEFA can be re-esterified in a variety of tissues. The liver, which is the principal site of re-esterification, incorporates NEFA into VLDL.

The metabolic processes involved in lipid assimilation and lipolysis are precisely regulated by neural, humoral and local factors released by, or in the neighbourhood of, the fat cells. In vivo studies on the regulation of lipolysis are always confronted with complex interactions between regulatory mechanisms and face major limitations concerning fat cell regulation and metabolism. The isolated fat cell and pre-adipocyte cell lines have been valuable systems for the delineation of the steps of the lipolytic cascade and the mechanisms of action of the various agents which contribute to its control. The in vitro approach allows the control of a number of variables in the fat cell environment (albumin levels, presence of various hormones and autacoids, and $\mathrm{pH}$ values). Nevertheless, the isolated fat cell system does not permit the determination of the respective 
physiological importance of all the lipolytic and anti-lipolytic regulators. Results obtained in vitro require in vivo validation whenever possible because large discrepancies have sometimes been revealed (Lillioja et al. 1986).

Fat deposition and energy storage aspects as well as the physiological aspects of fat mobilization have been well reviewed by others (Belfrage, 1985; Vernon \& Clegg, 1985; Frayn et al. 1992; Bülow, 1993; Coppack et al. 1994). The present review mainly focuses on recent advances obtained at the cellular level, concerning the nature and the role of the major pathways involved in the control of the lipolysis of fat-cell TAG and the mechanisms of selection of mobilized NEFA. HSL properties and the control of NEFA release by fat cells will be considered first. Then, the mechanisms of action and the relative importance of promoters and inhibitors of lipolysis which ensure the fine tuning of HSL activity and of NEFA availability will be discussed.

\section{HORMONE-SENSITIVE LIPASE}

HSL, the rate-limiting enzyme of the lipolytic cascade, catalyses the hydrolysis of triacylglycerol to diacylglycerol and, then to monoacylglycerol. The hydrolysis of the monoacylglycerol fatty acid bond is assured by monoacylglycerol lipase ( $E C$ 3.1.1.23). The abundance of this enzyme, which is not under hormonal control, is sufficient to avoid accumulation of intermediary lipolysis products (Fredrikson et al. 1986). HSL has a broad substrate specificity, hydrolysing tri- and diacylglycerols as well as cholesteryl esters. This latter property is unique for HSL compared with other lipases and is explained by the expression of HSL in steroid-producing tissues (testis, adrenal and ovary). Although all the triacylglycerol-hydrolysing lipases exhibit positional specificity for the 1(3)-ester bond, this specificity is less pronounced for HSL than for lipoprotein lipase or pancreatic lipase. Moreover, unlike these two lipases, HSL does not require a cofactor for full activity.

The hallmark of HSL, which distinguishes this enzyme from all other known lipases, is the control of its activity through phosphorylation. Fat-cell cAMP-dependent protein kinase ( $E C$ 2.7.1.37; cAMP-PK) phosphorylates HSL when activated by elevation of intracellular cAMP levels (Kawamura et al. 1981; Strålfors \& Belfrage, 1983). cGMPdependent protein kinase is only able to phosphorylate HSL in vitro (Strålfors \& Belfrage, 1985). In vitro assays, performed on isolated rat fat cells, have demonstrated that the phosphorylation of HSL parallels the activation of the enzyme. A single serine residue (regulatory site or site 1) is phosphorylated by cAMP-PK, $1 \mathrm{~mol}$ phosphate being incorporated per mol subunit (Strålfors \& Belfrage, 1983). The reversible phosphorylation of the regulatory site controls the activity state of the enzyme. Lipolytic activation is associated with an increase in phosphorylation of HSL, while anti-lipolytic action is associated with a decrease. The mechanism of activation of HSL through phosphorylation is still unclear. Curiously, the degree of activation of the purified enzyme by cAMP-PK-mediated phosphorylation is $2-3$-fold in vitro, while a more than 20 -fold increase in the lipolytic rate can be promoted by lipolytic agents in fat cells. However, it should be considered that in vitro assays using emulsified substrate do not offer optimized conditions of activation because of an increased availability of the substrate to the enzyme (Strålfors et al. 1987). It is clear that despite the changes in cAMP levels, the physicochemical state of the lipid droplets used in in vitro assays plays an important role in lipolytic processes (Okuda et al. 1992). Despite its unquestionable role as the 
gatekeeper of energy stores, questions remain open concerning the relationship between the subcellular distribution of HSL and its phosphorylation by cAMP-PK. In many ways, HSL behaves like an intrinsic membrane protein, e.g. it associates strongly with phospholipids, requires detergents for solubilization and exhibits an amphiphilic character (Holm et al. 1986). Redistribution of HSL may be a major event associated to phosphorylation and stimulation. On lipolytic stimulation, translocation of HSL from the cytosol to a particulate fraction was found in 3T3-L1 adipocytes (Hirsch \& Rosen, 1984). This view was recently strengthened. Using mild and appropriate disruption of rat adipocytes and HSL polyclonal antiserum, a translocation of phosphorylated HSL at the surface of the lipid droplet was demonstrated (Egan et al. 1992). The nature of the binding of the enzyme to a component of the droplet is not known. The primary structure of HSL does not show regions with high hydrophobicity which would clearly explain the propensity of phosphorylated HSL to bind directly to the lipid droplet. Reconsidering previous reports attributing a putative role to the lipid droplet substrate (Wise \& Jungas, 1978), it is tempting to consider that a protein component of the lipid droplet surface may undergo some kind of 'substrate activation', occurring concomitantly with HSL activation, and governing droplet-driven translocation of HSL. It could be speculated that, perilipins, specific adipocyte lipid-droplet-associated proteins, which could have a role in the packaging and/or the trafficking of lipids, are possible candidates in 'docking' proteins for HSL (Greenberg et al. 1991). These proteins probably contribute to the organization of lipid droplets and lipid vacuoles found in mature adipocytes (Hare et al. 1994). Perilipins are phosphorylated by cAMP-PK; in parallel with activation of lipolysis this could represent the 'substrate activation' process previously suggested (Wise \& Jungas, 1978). The recent isolation of cDNA for perilipins will allow detailed analysis of their role in fat cells (Greenberg et al. 1993).

In addition to the regulatory site (site 1 ), a second serine residue (basal site or site 2) can be phosphorylated. Three protein kinases: i.e. $\mathrm{Ca}^{2+} /$ calmodulin-dependent protein kinase II, the AMP-activated protein kinase and glycogen synthase kinase-4 (EC 2.7.1.37), have been demonstrated to phosphorylate site 2 in vitro (Olsson et al. 1986; Garton et al. 1989). Phosphorylation of site 2 of HSL does not directly alter HSL activity, but can exert a regulatory role since phosphorylation of site 1 and site 2 on HSL are mutually exclusive. Phosphorylation of site 2 makes site 1 inaccessible to cAMP-PK and prevents phosphorylation. Using a synthetic peptide based on the sequence surrounding sites 1 and 2 , it was shown that phosphorylation of the peptide at site 2 totally prevents the subsequent phosphorylation of site 1 and vice versa. It is unknown if such a mechanism operates in whole tissue (Garton et al. 1989; Garton \& Yeaman, 1990), although there is evidence that both site 1 and site 2 can be phosphorylated in vivo. A physiological mechanism involving AMP-activated kinase-dependent phosphorylation of HSL to block cAMP-PK-dependent phosphorylation and activation of the enzyme could represent a relevant regulatory possibility. A clue to the function of AMP-activated kinase is that the enzyme is activated by a 'kinase kinase', in turn activated by long-chain acyl-CoA esters at nanomolar concentrations. When the proportion of fatty acids, released by lipolytic processes and converted to the CoA esters, reaches a level which triggers the activation of 'kinase kinase' and AMP-dependent kinase, phosphorylation of site 2 of HSL could occur and prevent the cAMP-PK-dependent activation of the enzyme and release of further fatty acids. Much remains to be learned concerning the physiological relevance of the AMP-activated kinase pathways in the control of HSL 
function and lipolysis (Hardie et al. 1989; Yeaman, 1990). Direct feedback of HSL by oleoyl-CoA and oleic acid, in a non-competitive manner, has been demonstrated in in vitro assays (Jepson \& Yeaman, 1992); inhibition operates via binding of FA to a specific site on the enzyme protein. This coordinated feedback mechanism whereby elevated levels of fatty acids or fatty acyl-CoA regulate the level of free fatty acids in the cell, via inhibition of their mobilization from fat stores, is attractive, although its demonstration in vivo has proved difficult. The existence of various kinds of processes involved in the control of NEFA disposal (attachments to fatty acid-binding proteins (FABP), controlled outflow from the fat cell by FA transporter, limited access to cell compartments) complicates the delineation of the limiting steps.

HSL is a good substrate for phosphatases $2 \mathrm{~A}$ and $2 \mathrm{C}$ (EC 3.1.3.16; Olsson \& Belfrage, 1987). Phosphatases 1 and $2 \mathrm{~A}$ appear to contribute the major phosphatase activities within rat adipocytes, whereas phosphatase $2 \mathrm{C}$ is present at lower levels (Wood et al. 1993). Phosphatases $2 \mathrm{~A}$ and $\mathrm{C}$ exhibit similar degrees of activity towards the regulatory site, but the basal site is dephosphorylated predominantly by phosphatase $2 \mathrm{~A}$. It is considered that the hormonal control of phosphorylation-dephosphorylation of HSL occurs at the level of cAMP concentration rather than at the level of phosphatase activities (Manganiello et al. 1992).

CDNA for HSL have been obtained from both rat and human adipose tissue (Holm et al. 1988; Langin et al. 1993). Furthermore, the exon-intron organization of the human HSL gene has been elucidated (Langin et al. 1993). The human HSL gene is composed of nine exons spanning eleven kilobases and encodes a protein that is 786 amino acids long. The human and the rat proteins are $83 \%$ identical. The most important difference between the two sequences is a twelve amino acid deletion found in human HSL upstream of the phosphorylation site region. The functional importance of this deletion, if any, is not clarified. Each putative functional region of HSL is encoded by a different exon, suggesting that HSL could be a mosaic protein. Exon 6 contains a motif for the catalytic serine (Ser423) found in most lipases. Site-directed mutagenesis of the serine residue leads to the complete abolition of the lipase activity (Holm et al. 1994b). The phosphorylation site sequence (Met-Arg-Arg-Ser551-Val-Ser553-Glu-Ala-Ala) is encoded by exon 8 ; it is completely preserved in bovine, rat and mouse HSL. Exon 9 encodes a short hydrophobic stretch which has been identified as a potential lipid-binding region.

HSL shares no homology with known eukaryotic proteins. In particular, HSL does not belong to the so-called lipase gene family that includes lipoprotein lipase, hepatic lipase and pancreatic lipase. However, it does show sequence similarity to five prokaryotic enzymes from distantly related eubacteria (Langin \& Holm, 1993). The region of similarity is bordered by the catalytic site motif which is identical in the six proteins and a His-Gly dipeptide which may constitute one of the hydrophobic 'wings' flanking the catalytic site. The strongest sequence similarity is found with lipase 2 of Moraxella $T A 144$, an antarctic psychrotrophic bacterium. Since lipase 2 catalyses lipolysis below $4^{\circ}$, the cold adaptability of HSL, an unexpected property for a mammalian lipase, was investigated. HSL retained distinctly more catalytic activity at low temperatures than either lipoprotein lipase or carboxyl ester lipase. The so-called 'cold adaptability' of HSL has recently been discussed (Langin et al. 1993; Langin \& Holm, 1993). This unexpected property of HSL could be of critical survival value when lipids mobilized at low temperatures are the primary energy sources, e.g. in hibernators or poikilotherms. 
Although poorly investigated for the moment, HSL activity may be partially governed by alterations in the degree of gene expression. Some recent studies have shown that the HSL gene is differentially expressed and regulated in tissues during growth and development (Kraemer et al. 1991; Sztalryd \& Kraemer, 1994a) and fasting (Sztalryd \& Kraemer, 1994b). HSL mRNA levels have been found to be increased in the subcutaneous adipose tissue of cancer patients (Thompson et al. 1993). The authors suggested that this increase could be one of the mechanisms involved in the depletion of lipid from adipose tissues in these patients. However, it would be useful to assess whether the changes observed in HSL expression are sufficient to have physiological relevance.

The resolution of the 3-D structure of HSL and mapping of functional domains by site-directed mutagenesis will provide major improvements for the elucidation of structure-function relationships of HSL. A recent expression system utilizing recombinant baculovirus carrying a full-length rat HSL cDNA downstream from the polyhedrin promoter in insect cells has allowed production of large amounts of functional recombinant HSL protein. It is expected that determination of the 3-D structure of HSL by crystallization studies will be considerably facilitated (Holm et al. 1994a).

The chromosomal mapping of the HSL gene was performed in humans and mice. The human HSL gene is located on chromosome 19q13.1 (Holm et al. 1988; Schonk et al. 1990), while the mouse gene is positioned approximately $8 \mathrm{cM}$ from the centromere of chromosome 7 (Warden et al. 1993). However, a recent analysis showed that at least one portion of the HSL gene or a pseudogene could also be mapped to 19p13.3 (Jedlicka et al. 1994). Precise knowledge of the HSL gene chromosomal location and the possibility of gene duplication are critical for genetic linkage analyses and the studies of the regulatory elements involved in HSL gene expression. The combined knowledge of HSL chromosomal location and the structure of the $5^{\prime}$-flanking region of the gene should open new possibilities in the study of the transcriptional regulation of the enzyme and in the search for a putative involvement of the HSL gene in inherited disorders of lipid metabolism.

\section{MOBILIZATION OF FATTY ACIDS STORED IN ADIPOSE TISSUE}

Fatty acid composition of adipose tissue TAG is rather complex and fifty to sixty individual FA varying in chain length, degree of saturation and position of double bonds exist. An important point concerns the relationship existing between the content of FA in the TAG and their mobilizing opportunities. The question which has often been posed is whether a differential release of FA, depending on their molecular structure and ester bond position, exists in fat cells. Adipose-tissue FA profiles roughly correlate with dietary lipid composition, adipose tissue containing a higher proportion of saturated FA compared with polyunsaturated FA (PUFA) relative to other tissues and organs. The tendency for adipose tissue to store saturated FA rather than PUFA suggests that: (1) PUFA precursors are not trapped at the same rate within the adipose tissue, (2) preferential mobilization of PUFA occurs, maintaining low levels in fat cells. The idea that the release of FA from adipose tissue is not just a random process has been considered for a long time. Various studies, limited to a small number of FA ranging from $\mathrm{C}_{14}$ to $\mathrm{C}_{18}$ and no double bonds to three double bonds have been performed, but have not provided convincing evidence for the existence of a differential mobilization.

A recent study of the differential mobilization of FA has been performed for almost all 
the FA that can be found in the adipose tissue of mammals. The relative mobilization of FA was investigated after an in vitro stimulation of lipolysis in fat cells from rats maintained on a laboratory chow or a fish-oil diet. The study has convincingly demonstrated that, under conditions of stimulated lipolysis, FA are more readily mobilized from fat cells when they are short and unsaturated and when the double bonds are closer to the methyl end of the chain (Raclot \& Groscolas, 1993). The phenomenon was observed in the fat cells of rats conditioned with both kinds of diets and does not seem to be linked to the fish-oil diet. Recently, a preferential release of two polyunsaturated FA (18:3n-3 and 20:4n-6) over three other FA (16:0, 18:1n-9 and 18:2n6) has also been demonstrated in three experimental models representing different degrees of complexity: (1) cultured pre-adipocytes containing PUFA-enriched TAG, (2) perfused epididymal rat fat pads and (3) in vitro incubations of crude preparations of HSL with synthetic triacylglycerol analogues as substrates (Gavino \& Gavino, 1992). Whatever the experimental strategies, these recent results support the idea that FA are not mobilized from fat cells in direct proportion to their TAG content. A study of triacylglycerol metabolism in 3T3-L1 cells using ${ }^{13} \mathrm{C}$ NMR spectroscopy has shown that HSL could exhibit a preference for certain TAG species under conditions of stimulation of lipolysis but little under the basal ones (Soma et al. 1992). It is noticeable that differential mobilization of FA has also been reported in the emperor penguin (Aptenodytes forsteri) in vivo in situations of enhanced fat mobilization (Groscolas, 1990). Differential release of FA from fat cells can result from the distribution of TAG in the lipid droplet and a differential mobilization could be explained by the physical availability of substrate to HSL at the lipid-water interface (Brockman, 1984). The more polar TAG (the richer in polar FA) would be preferentially located at the periphery of the lipid droplet and more accessible to hydrolysis by HSL (Raclot \& Groscolas, 1993).

It is likely that differences in hydrophilicity (that is a differential physicochemical property) is the basis of differential mobilization of FA, due in part to the preference of HSL for PUFA. This HSL-mediated preferential release of PUFA from adipose TAG suggests a role played by the enzyme in the control of the positioning of FA on the TAG backbone (1- and 3-acyl moieties tend to be saturated while the 2-acyl moiety tends to be unsaturated; Gavino \& Gavino, 1992). Various steps exist between HSL action at the lipid droplet, the transfer of NEFA to plasma membrane and their extrusion into the extracellular space. The fatty acid-binding protein ALBP, also known as aP2, an adipocyte cytosolic protein, is considered to bind long-chain FA and to contribute to shuttling them between the various compartments of the fat cell. It is involved in the transfer of NEFA from the cytosol to the membranes and could operate through aqueous-phase diffusion more rapidly transferring the shorter and more unsaturated FA (PUFA, i.e. the more water soluble; Potter et al. 1989). This more rapid ALBP. dependent transfer makes PUFA less available for re-esterification and good candidates for preferential efflux. NEFA transport across the fat cell membrane is also a highly specific phenomenon which involves specific proteins (Abumrad et al. 1984, 1986, 1993; Potter et al. 1989). This high-affinity membrane transport system for long-chain FA could also play a role in maintaining lower PUFA levels in fat cells. The re-esterification pathway may also be a factor for the preferential release of PUFA if re-esterification of the saturated FA in TAG operates more rapidly than that for PUFA. This process has been little investigated in vitro and is rather difficult to interpret due to the incidence of assay conditions where, generally, enough NEFA carrier (albumin) is present to trap 
NEFA away from the adipocyte. Recent studies suggest that the re-esterification pathway operates by an extracellular route where NEFA originating from TAG hydrolysis and exported from the fat cell have to be taken up again to be esterified (Leibel \& Hirsch, 1985; Edens et al. 1990). Finally, to clarify the putative importance of the various mechanisms involved in PUFA disposal, the recent results obtained in acute experiments using the crude HSL preparation model of Gavino (Gavino \& Gavino, 1992; e.g. 'pH 5.2 precipitate' preparations of rat HSL from perirenal and epididymal rat fat pads catalysing the hydrolysis of a synthetic TAG), which is not affected by re-esterification of NEFA due to absence of free $\mathrm{CoA}$ in the assay, supports the idea that the preference of HSL for PUFA plays an important role in their preferential mobilization.

From a physiological point of view, existence of a differential mobilization of PUFA from TAG in the rat fat cell probably explains differences in storage and oxidation of FA obtained with various fat diets. This mechanism may be important in the control of the FA composition of adipose tissue, a tendency for the preferential mobilization of certain FA is necessarily associated with diminished storage by preventing excessive trapping of PUFA in fat deposits. Short-chain and unsaturated FA, which are known to reduce adipose tissue development and body mass gain, could lead to preferential mobilization from fat deposits. It is also noticeable that the major precursors of eicosanoids, i.e. arachidonic acid and eicosapentaenoic acid, are preferentially mobilized from adipose tissue. These FA are at the origin of agents such as prostaglandins $\mathbf{P G E}_{2}$ and $\mathrm{PGI}_{2}$ which are known to exert potent anti-lipolytic actions (Richelsen, 1987, 1991) and adipogenic effects respectively (Catalioto et al. 1991; Vassaux et al. 1992).

\section{CONTRIBUTION OF ADENYLYLCYCLASE (EC 4.6.1.1)-COUPLED MEMBRANE RECEPTORS TO METABOLIC EFFECTS AND NON-ESTERIFIED FATTY ACID MOBILIZATION}

Studies of isolated fat cells from humans and other species have revealed the complexity of the control of lipolysis by adenylylcyclase (EC 4.6.1.1)-coupled receptors and insulin. For the time being, it is commonly accepted that lipolysis is mainly controlled by sympathetic nervous system activity and plasma insulin levels. Basically, the lipolytic response of the fat cell depends on the balanced action of stimulatory and inhibitory pathways on HSL activity. Receptors which, when stimulated, are activators of adenylylcyclase and of HSL activity have been studied quite extensively in fat cells. Conversely, the diverse and numerous adenylylcylase-coupled inhibitory receptor pathways represent the neglected side of fat cell function for a large number of biologists.

The different steps of the lipolytic process leading to the activation of HSL are quite well defined (Lafontan \& Berlan, 1993). The first cellular action of catecholamines, and a number of endocrine-paracrine regulators of lipolysis, is their binding to plasma membrane receptors. The stimulatory effect on lipolysis is strictly connected to the receptor-controlled increment of intracellular cAMP concentrations which in turn promotes activation of cAMP-PK (Honnor et al. 1985a) which phosphorylates HSL. In addition to its effect on HSL, cAMP-PK could also catalyse the phosphorylation of many other proteins in fat cells; some of them having a role in the control of metabolic events such as glycogenolysis and insulin-induced glucose uptake. In addition to HSL, the best-identified substrates for cAMP-PK in fat cells are perilipins, glucose transporter 
GLUT4, cGMP-inhibited low $K_{m}$ cAMP-phosphodiesterase (EC 3.1.4.17; cGI-PDE), phosphorylase kinase ( $E C$ 2.7.1.38), glycogen synthase ( $E C$ 2.4.1.11), acyl-CoA carboxylase and the $\beta 1$ - and $\beta 2$-adrenoceptors themselves (Lafontan \& Berlan, 1993). It remains difficult to clarify the operative sites of cAMP-PK phosphorylation in its numerous target proteins in in vivo conditions.

The first step leading to activation of the lipolytic cascade, involves the multi-regulated key enzyme, adenylylcyclase, which produces cAMP. Detailed mechanistic considerations have recently been reviewed (Lafontan \& Berlan, 1993). Catecholamines are the most sophisticated regulators of fat cell function since they operate through several separate receptors. They are able to stimulate three subtypes of $\beta$-adrenoceptors which are positively coupled to adenylylcyclase by Gs proteins, and an $\alpha 2$-adrenoceptor negatively coupled to the enzyme by a Gi protein. An important point in the metabolic actions initiated by endocrine and paracrine regulators concerns the functional significance of intracellular cAMP elevations promoted by receptor-mediated adenylylcyclase control. In fat cells, the lipolytic agents promote cAMP increments which largely cover the needs required for maximal activation of cAMP-PK and lipolysis (Fain \& GarciaSainz, 1983; Honnor et al. 1985a). A detailed quantitative study of the relationships existing between intracellular cAMP levels, cAMP-PK activity and lipolysis has been performed in rat fat cells. The absence of correlation between cAMP levels, cAMP-PK activity state and lipolytic responsiveness was demonstrated for sustained and submaximal activation of fat cells (Honnor et al. 1985a,b; Langin et al. 1992). Nevertheless, quantitative differences in the cAMP-lipolysis relationships have been reported when comparing the effects of various lipolytic agents. The existence of cAMP-independent lipolytic responses and of cAMP compartmentalization have been proposed to explain such discrepancies (Allen \& Quesenberry, 1988; Hollenga et al. 1991; Murphy et al. 1993). The validity of the concept of different pools of intracellular cAMP is still questioned. Nevertheless, in recent years it has become apparent that a significant proportion of type II cAMP-dependent protein kinases are compartmentalized in specific sites of the cell (Scott \& McCartney, 1994). Co-location of cAMP-PK with its substrates is a potential mechanism to explain how a multi-functional kinase with a broad substrate specificity can mediate the precise biochemical events associated with its activation by individual hormones. Finally, in addition to its metabolic role, the adrenoceptoractivated cAMP signalling pathway is also involved in the control of the adipose conversion of various adipose cell lines and exerts positive and/or negative effects on adipose gene expression.

In fat cells, when focusing on lipolysis regulation, the stimulation of the three $\beta$-adrenoceptors leads to elevations of intracellular cAMP levels and lipolysis stimulation. Differential recruitment of the various $\beta$-adrenoceptor subtypes has clearly been established in vitro and in vivo in dog (Galitzky et al. 1993a,b) and rat fat cells, with an order of affinity which is $\beta 1>\beta 2>\beta 3$. $\beta 3$-Adrenoceptors are recruited in dog and rat fat cells when the highest concentrations of catecholamines are reached. Nevertheless, these receptors are not very efficient in primate and human adipocytes. In human fat cells, it is the $\alpha 2$-adrenoceptor which has the highest affinity for physiological amines and is recruited at the lowest catecholamine concentrations before the activation of $\beta$-adrenoceptors can occur. Biphasic regulation of lipolysis by catecholamines has been demonstrated clearly in human fat cells (Berlan \& Lafontan, 1985; Mauriège et al. 1987; Lafontan \& Berlan, 1993). The interplay between $\alpha 2$ - and $\beta$-adrenoceptors takes a key 
position in the triggering of cAMP increments in fat cells; species-specific discrepancies exist and $\alpha 2$-adrenergic responsiveness is increased by fat cell hypertrophy (Lafontan $\&$ Berlan, 1993). Besides HSL activation, cAMP increase also promotes $\beta 2-$ $\beta 1$-adrenoceptor desensitization which can be explained partly by cAMP-PK-dependent receptor phosphorylation (Hausdorff et al. 1990). Such a mechanism could limit the occurrence of sustained $\beta$-receptor-driven cAMP production. In addition, cAMP-PKdependent phosphorylation and activation of cGI-PDE, which could exert some sort of feedback mechanism on cAMP levels, was also demonstrated (Degerman et al. 1990; Manganiello et al. 1992). The phosphorylation site for cAMP-PK on the isolated rat adipocyte cGI-PDE has been identified recently. Serine 427 of cGI-PDE is the target for cAMP-PK phosphorylation of the rat adipocyte cGI-PDE in vitro (Rascon et al. 1994). Although in fat cells most of the experimental data can be explained by cAMP-PK activation, high cAMP levels could activate other forms of cAMP-dependent protein kinases or other effectors of cell activation which could be involved in pathways controlling FA processing in white fat cells.

\section{METABOLIC EFFECTS MEDIATED BY INSULIN AND TYROSINE-KINASE-COUPLED MEMBRANE RECEPTORS}

Insulin, the anti-lipolytic hormone, was initially considered to cause dephosphorylation of HSL and its deactivation through phosphatase activation. However, insulindependent cGI-PDE activation, increasing cAMP degradation, has been convincingly demonstrated (Degerman et al. 1990). This enzyme, with a subunit relative molecular mass of 135000 determined by SDS-PAGE has been purified from rat adipose tissue and its cDNA has recently been cloned and sequenced (Taira et al. 1993).

Insulin is the most physiologically important and potent inhibitor of basal and hormone-stimulated lipolysis and NEFA output. Its action is probably linked to a decrease in cellular cAMP levels. Insulin-induced reduction of cAMP could result from the inhibition of adenylylcyclase and/or from a stimulation of cGI-PDE. The effects through adenylylcyclase inhibition are still largely questionable and Gi proteins do not play a noticeable role, if any, in the transduction of the insulin signal in the adipocytes (Wesslau et al. 1993). Several investigators have shown activation of particulate cGI-PDE in 3T3-L1 cells and rat and human adipocytes. Having access to recently developed molecules, the anti-lipolytic effects of insulin were shown to be dosedependently blocked by the highly specific inhibitor of cGI-PDE, OPC 3911 (Manganiello et al. 1992; Wesslau et al. 1993). Results obtained in intact adipocytes are consistent with the notion that, in addition to cAMP-PK-dependent phosphorylation of cGI-PDE, insulin catalyses the phosphorylation of cGI-PDE on separate serine site(s) and promotes its activation.

Intracellular cAMP levels are very important in modulating insulin sensitivity and action. The anti-lipolytic effect of insulin is impaired with high levels of cAMP and when cAMP-PK activity ratio exceeds 0.6 in rat adipocytes (Londos et al. 1985). Discrepancies in insulin-induced anti-lipolytic effects reported by various investigators are probably linked to the nature of the assay system used to promote increments of cAMP levels before measuring the anti-lipolytic effects of insulin. Since there is a non-linear relationship between lipolysis and cAMP levels, an impairment of the anti-lipolytic action of insulin appears when insulin-induced cGI-PDE activation is not sufficient to 
promote a reduction in the cAMP levels, to such an extent that inhibition of lipolysis could occur.

\section{CONCLUSIONS AND FUTURE TRENDS}

The white fat cell is the major site of FA storage in the TAG form. NEFA constitute a major class of endogenous compounds since, in addition to the fact that they constitute a main energy source because of their high energy content, they are components of membranes and precursors of many biologically active substances which in turn affect many cell functions. FA have been demonstrated to be involved in the regulation of the expression of various adipose genes (Amri et al. 1991; Distel et al. 1992) and PUFA have been shown to be able to contribute to lipid metabolism through activation of peroxisome proliferator-activated receptors (Keller \& Wahli, 1993). The present review has dealt with recent data on the HSL gene and regulatory processes involved in the control of HSL activity. Further studies will be needed to delineate all pre- and post-translational mechanisms contributing to the control of HSL expression and activity. The recent results on the differential mobilization of NEFA from the white-fatcell TAG stores, when lipolysis is enhanced, are discussed. It is important to understand the mechanisms controlling essential PUFA release and their disposal in fat depots and circulation, as regulation of the expression of genes involved in lipid metabolism by PUFA could be of great physiological and clinical importance.

Concerning the hormonal control of white-fat-cell lipolysis and NEFA release, the contribution of each $\beta$-adrenoceptor subtype in the adrenergic control of lipolysis has been clarified. Large species-specific differences exist and various aspects of the differential recruitment and differential regulations of $\beta$-adrenoceptors in white fat cells require further studies. When considering anti-lipolytic systems, apart from insulin which could be considered as being the major anti-lipolytic agent acting through cGI-PDE activation, adenylylcyclase-coupled inhibitory receptors of the fat cell, although diverse and numerous, represent the neglected part of fat cell function. The inhibitory arm of the fat-cell adenylylcyclase probably acts to counter-regulate the stimulatory arm. Lipolysis is the result of increased stimulation without change in inhibition, or of reduction in inhibition without changes in stimulation, or is a mixture of both events. The most suitable conditions for exploring the involvement of both systems under balanced conditions are not reached in vitro. In general terms, when using the isolated-fat-cell preparation, it is difficult to delineate the optimized balanced proportion of the various components of the buffer system which could permit the most physiologically relevant 'setting' of the so-called 'basal rate of lipolysis' in vitro.

Numerous differences reported in humans and animals between intra-abdominal and subcutaneous depots and even within the various subcutaneous depots show that each adipose tissue deposit has its own specificity in terms of its lipolytic and anti-lipolytic systems. These systems permit TAG to be hydrolysed at different rates from fat cells of the different regions. Regional differences in HSL expression and fat-cell stimulators and inhibitors of adenylylcyclase may explain why fat tends to accumulate more specifically in particular adipose tissue sites. The diversity and the site differences reported in anti-lipolytic pathways involving numerous effectors produced in highly variable physiological or pathological conditions, suggest that they could represent an important part of the lipolytic system. It is expected that the development of in vivo approaches using 
in situ microdialysis will facilitate the analysis of the agents released in the vicinity of the fat cells. The study of their direct action on fat cells and the vascular bed will be considerably facilitated. Moreover, in the near future, genetic and immunological techniques. should enable detailed analyses of the enzymes and pathways of the signal transduction system of the fat cell. The cell-targeted 'knock out' of various genes coding for the numerous elements of the pathways controlling NEFA mobilization will open new perspectives for the delineation of their physiological relevance.

\section{REFERENCES}

Abumrad, N. A., El-Maghrabi, M. R., Amri, E.-Z., Lopez, E. \& Grimaldi, P. A. (1993). Cloning of rat adipocyte membrane protein implicated in binding and transport of long-chain fatty acids that is induced during preadipocyte differentiation. Homology with human CD36. Journal of Biological Chemistry 268, $17665-17668$.

Abumrad, N. A., Park, J. H. \& Park, C. R. (1984). Permeation of long chain fatty acids into adipocytes: kinetics, specificity, and evidence for involvement of a membrane protein. Journal of Biological Chemistry 259, 8945-8953.

Abumrad, N., Park, C. R. \& Whitesell, R. R. (1986). Catecholamine activation of the membrane transport of long chain fatty acids in adipocytes is mediated by cyclic AMP and protein kinase. Journal of Biological Chemistry 261, 13082-13086.

Allen, D. O. \& Quesenberry, J. T. (1988), Quantitative differences in the cyclic AMP-lipolysis relationships for isoproterenol and forskolin. Journal of Pharmacology and Experimental Therapeutics 244, 852-858.

Amri, E.-Z., Bertrand, B., Ailhaud, G. \& Grimaldi, P. (1991). Regulation of adipose cell differentiation: I. Fatty acids are inducers of the aP2 gene expression. Journal of Lipid Research 32, 1449-1456.

Belfrage, P. (1985). Hormonal control of lipid degradation. In New Perspectives in Adipose Tissue: Structure, Function and Development, pp. 121-144 [A. Cryer and R. L. R. Van, editors]. London: Butterworths.

Bensadoun, A. (1991). Lipoprotein lipase. Annual Review of Nutrition 11, 217-237.

Berlan, M. \& Lafontan, M. (1985). Evidence that epinephrine acts preferentially as an antilipolytic agent in abdominal human subcutaneous fat cells: assessment by analysis of beta- and alpha2-adrenoceptors properties. European Journal of Clinical Investigation 15, 341-346.

Brockman, H. L. (1984). General features of lipolysis: reaction scheme, interfacial structure and experimental approaches. In Lipases, pp. 3-46 [B. Borgström and H. L. Brockman, editors]. Amsterdam, The Netherlands: Elsevier.

Bülow, J. (1993). Lipid mobilization and utilization. In Principles of Exercise Biochemistry, Medicine and Sport Science, 2nd ed., pp. 158-185 [J. R. Poortmans, editor]. Basel, Switzerland: Karger.

Catalioto, R.-M., Gaillard, D., Maclouf, J., Ailhaud, G. \& Negrel, R. (1991). Autocrine control of adipose cell differentiation by prostacyclin and PGF2alpha. Biochimica et Biophysica Acta 1091, 364-369.

Coppack, S. W., Jensen, M. D. \& Miles, J. M. (1994). In vivo regulation of lipolysis in humans. Journal of Lipid Research 35, 177-193.

Degerman, E., Smith, C. J., Tornqvist, H., Vasta, V., Belfrage, P. \& Manganiello, V. C. (1990). Evidence that insulin and isoprenaline activate the cGMP-inhibited low Km cAMP-phosphodiesterase in rat fat cells by phosphorylation. Proceedings of the National Academy of Sciences USA 87, 533-537.

Distel, R. J., Robinson, G. S. \& Spiegelman, B. M. (1992). Fatty acid regulation of gene expression. Transcriptional and post-transcriptional mechanisms. Journal of Biological Chemistry 267, 5937-5941.

Edens, N. K., Leibel, R. L. \& Hirsch, J. (1990). Mechanisms of free fatty acid re-esterification in human adipocytes in vitro. Journal of Lipid Research 31, 1423-1431.

Egan, J. J., Greenberg, A. S., Chang, M.-K., Wek, S. A., Moos, M. C. Jr \& Londos, C. (1992). Mechanism of hormone-stimulated lipolysis in adipocytes: Translocation of hormone-sensitive lipase to the lipid storage droplet. Proceedings of the National Academy of Sciences USA 89, 8537-8541.

Enerbäck, S. \& Grimble, J. M. (1993). Lipoprotein lipase gene expression: physiological regulators at the transcriptional and post-transcriptional level. Biochimica et Biophysica Acta 1169, 107-125.

Fain, J. N. \& Garcia-Sainz, J. A. (1983). Adrenergic regulation of adipocyte metabolism. Journal of Lipid Research 24, 945-966.

Frayn, K. N., Coppack, S. W. \& Potts, J. L. (1992). Effect of diet on human adipose tissue metabolism. Proceedings of the Nutrition Society 51, 409-418. 
Fredrikson, G., Tornqvist, H. \& Belfrage, P. (1986). Hormone-sensitive lipase and monoacylglycerol lipase are both required for complete degradation of adipocyte triacylglycerol. Biochimica et Biophysica Acta 876, 288-293.

Galitzky, J., Reverte, M., Carpene, C., Lafontan, M. \& Berlan, M. (1993a). Beta3-adrenoceptors in dog adipose tissue: studies on their involvement in the lipomobilizing effect of catecholamines. Journal of Pharmacology and Experimental Therapeutics 266, 358-366.

Galitzky, J., Reverte, M., Portillo, M., Carpene, C., Lafontan, M. \& Berlan, M. (1993b). Coexistence of functional beta1-, beta2- and beta3-adrenoceptors in dog fat cells and their differential activation by catecholamines. American Journal of Physiology 264, E403-E412.

Garton, A. J., Campbell, D. G., Carling, D., Hardie, D. G., Colbran, R. J. \& Yeaman, S. J. (1989). Phosphorylation of bovine hormone-sensitive lipase by the AMP-activated protein kinase. A possible antilipolytic mechanism. European Journal of Biochemistry 179, 249-254.

Garton, A. J. \& Yeaman, S. J. (1990). Identification and role of the basal phosphorylation site on hormone-sensitive lipase. European Journal of Biochemistry 191, 245-250.

Gavino, V. C. \& Gavino, G. R. (1992). Adipose hormone-sensitive lipase preferentially releases polyunsaturated fatty acids from triglycerides. Lipids 27, 950-954.

Greenberg, A., Egan, J. J., Wek, S. A., Garty, N. B., Blanchette-Mackie, E. J. \& Londos, C. (1991). Perilipin, a major hormonally regulated adipocyte-specific phosphoprotein associated with the periphery of lipid storage droplets. Journal of Biological Chemistry 266, 11341-11346.

Greenberg, A. S., Egan, J. J., Wek, S. A., Moos, M. C. Jr, Londos, C. \& Kimmel, A. R. (1993). Isolation of cDNAs for perilipins A and B: sequence and expression of lipid droplet-associated proteins of adipocytes. Proceedings of the National Academy of Sciences USA 90, 12035-12039.

Groscolas, R. (1990). Metabolic adaptations to fasting in emperor and king penguins. In Penguin Biology, pp. 269-295 [L. S. Davis and J. T. Darby, editors]. San Diego, CA: Academic Press.

Hardie, D. G., Carling, D. \& Sim, A. T. R. (1989). The AMP-activated protein kinase: a multisubstrate regulator of lipid metabolism. Trends in Biochemical Sciences 14, 20-23.

Hare, J. F., Taylor, K. \& Holocher, A. (1994). Energy-dependent protein glycerol interaction in a cell-free system from 3T3-L1 adipocytes. Journal of Biological Chemistry 269, 771-776.

Hausdorff, W. P., Caron, M. G. \& Lefkowitz, R. J. (1990). Turning off the signal: desensitization of beta-adrenergic receptor function. FASEB Journal 4, 2881-2889.

Hirsch, A. H. \& Rosen, O. M. (1984). Lipolytic stimulation modulates the subcellular distribution of hormone-sensitive lipase in 3T3-L1 cells. Journal of Lipid Research 25, 665-677.

Hollenga, C., Brouwer, F. \& Zaagsma, J. (1991). Relationship between lipolysis and cyclic AMP generation mediated by atypical beta-adrenoceptors. British Journal of Pharmacology 102, 577-580.

Holm, C., Belfrage, P., Osterlund, T., Davis, R. C., Schotz, M. C. \& Langin, D. (1994a). Hormone-sensitive lipase: structure, function, evolution and overproduction in insect cells using the baculovirus expression system. Protein Engineering 7, 537-541.

Holm, C., Davis, R. C., Osterlund, T., Schotz, M. C. \& Fredrikson, G. (1994b). Identification of the active site serine of hormone-sensitive lipase by site-directed mutagenesis. FEBS Letters 344, 234-238.

Holm, C., Fredrikson, G. \& Belfrage, P. (1986). Demonstration of the amphiphilic character of hormonesensitive lipase by temperature-induced phase separation in Triton X 114 and charge-shift electrophoresis. Journal of Biological Chemistry 261, 15659-15661.

Holm, C., Kirchgessner, T. G., Svensson, K. L., Fredrikson, G., Nilsson, S., Miller, C. G., Shively, J. E., Heinzemann, C., Sparkes, R. S., Mohandas, T., Lusis, A. J., Belfrage, P. \& Schotz, M. C. (1988). Hormone-sensitive lipase: sequence, expression and chromosomal localization to 19 cent q13.3. Science 241, 1503-1506.

Honnor, R. C., Dhillon, G. S. \& Londos, C. (1985a). cAMP-dependent protein kinase and lipolysis in rat adipocytes. I. Cell preparation, manipulation and predictability in behaviour. Journal of Biological Chemistry 260, 15122-15129.

Honnor, R. C., Dhillon, G. S. \& Londos, C. (1985b). cAMP-dependent protein kinase and lipolysis in rat adipocytes. II. Definition of steady-state relationship with lipolytic and antilipolytic modulators. Journal of Biological Chemistry 260, 15130-15138.

Jedlicka, A. E., Taylor, E. W., Meyers, D. E., Liu, Z. \& Levitt, R. C. (1994). Localization of the highly polymorphic locus D19S120 to 19p13.3 by linkage. Cytogenetics and Cell Genetics 65, 140.

Jepson, C. A. \& Yeaman, S. J. (1992). Inhibition of hormone-sensitive lipase by intermediary lipid metabolites. FEBS Letters 310, 197-200. 
Kawamura, M., Jensen, D. F., Wancewicz, E. V., Joy, L. L., Khoo, J. C. \& Steinberg, D. (1981). Hormone-sensitive lipase in differentiated 3T3-L1 cells and its activation by cyclic AMP-dependent protein kinase. Proceedings of the National Academy of Sciences USA 78, 732-736.

Keller, H. \& Wahli, W. (1993). Peroxisome proliferator-activated receptors. A link between endocrinology and nutrition. Trends in Endocrinology and Metabolism 4, 291-296.

Kraemer, F. B., Tavangar, K. \& Hoffmann, A. R. (1991). Developmental regulation of hormone-sensitive lipase mRNA in the rat: changes in steroidogenic tissues. Journal of Lipid Research 32, 1303-1310.

Lafontan, M. \& Berlan, M. (1993). Fat cell adrenergic receptors and the control of white and brown fat cell function. Journal of Lipid Research 34, 1057-1091.

Langin, D., Ekholm, D., Ridderstrale, M., Lafontan, M. \& Belfrage, P. (1992). cAMP-dependent protein kinase activation mediated by $\beta 3$-adrenergic receptors parallels lipolysis in rat adipocytes. Biochimica et Biophysica Acta $1135,349-352$.

Langin, D. \& Holm, C. (1993). Sequence similarities between hormone-sensitive lipase and five prokaryotic enzymes. Trends in Biochemical Sciences 18, 466-467.

Langin, D., Laurell, H., Holt, L. S., Belfrage, P. \& Holm, C. (1993). Gene organization and primary structure of human hormone-sensitive lipase: possible significance of a sequence homology with a lipase of Moraxella TA144, an antarctic bacterium. Proceedings of the National Academy of Sciences USA 90, 4897-4901.

Leibel, R. L. \& Hirsch, J. (1985). A radioisotopic technique for analysis of free fatty acid reesterification in human adipose tissue. American Journal of Physiology 248, E140-E147.

Lillioja, S., Foley, J. E., Bogardus, D., Mott, D. M. \& Howard, B. V. (1986). Free fatty acid metabolism and obesity in man: in vivo and in vitro comparisons. Metabolism 35, 505-514.

Londos, C., Honnor, R. C. \& Dhillon, G. S. (1985). cAMP-dependent protein kinase and lipolysis in rat adipocytes. III. Multiple modes of insulin regulation of lipolysis and regulation of insulin responses by adenylate cyclase regulators. Journal of Biological Chemistry 260, 15139-15145.

Manganiello, V. C., Degerman, E., Smith, C. J., Vasta, V., Tornqvist, H. \& Belfrage, P. (1992). Mechanisms for activation of the rat adipocyte particulate cyclic-GMP-inhibited cyclic AMP phosphodiesterase and its importance in the antilipolytic action of insulin. In Advances in Second Messenger and Phosphoprotein Research, pp. 147-164 [S. J. Strada and H. Hidaka, editors]. New York: Raven Press Ltd.

Mauriège, P., Galitzky, J., Berlan, M. \& Lafontan, M. (1987). Heterogeneous distribution of beta- and aipha2-adrenoceptor binding sites in human fat cells from various fat deposits: functional consequences. European Journal of Clinical Investigation 17, 156-165.

Murphy, G. J., Kirkham, D. M., Cawthorne, M. A. \& Young, P. (1993). Correlation of beta3-adrenoceptorinduced activation of cyclic AMP-dependent protein kinase with activation of lipolysis in rat white adipocytes. Biochemical Pharmacology 46, 575-581.

Okuda, H., Morimoto, C. \& Tsujita, T. (1992). Relationship between cyclic AMP production and lipolysis induced by forskolin in rat fat cells. Journal of Lipid Research 33, 225-231.

Olsson, H. \& Belfrage, P. (1987). Dephosphorylation of the regulatory phosphorylation site of hormonesensitive lipase in rat adipocytes: Evidence for a dominant role of protein phosphatase-2A. European Journal of Biochemistry 168, 399-405.

Olsson, H., Strålfors, P. \& Belfrage, P. (1986). Phosphorylation of the basal site of hormone-sensitive lipase by glycogen synthase kinase-4. FEBS Letters 209, 175-180.

Potter, B. J., Sorrentino, D. \& Berk, P. D. (1989). Mechanisms of cellular uptake of free fatty acids. Annual Review of Nutrition 9, 253-270.

Raclot, T. \& Groscolas, R. (1993). Differential mobilization of white adipose tissue fatty acids according to chain length, unsaturation, and positional isomerism. Journal of Lipid Research 34, 1515-1526.

Rascon, A., Degermai, E., Taira, M., Meacci, E., Smith, C. J., Manganiello, V., Belfrage, P. \& Tornqvist, H. (1994). Identification of the phosphorylation site in vitro for cAMP-dependent protein kinase on the rat adipocyte cGMP-inhibited cAMP phosphodiesterase. Journal of Biological Chemistry 269, 11962-11966.

Richelsen, B. (1987). Factors regulating the production of prostaglandin $E_{2}$ and prostacyclin (prostaglandin $I_{2}$ ) in rat and human adipocytes. Biochemical Journal 247, 389-394.

Richelsen, B. (1991). Prostaglandins in adipose tissue. Danish Medical Bulletin 38, 228-244.

Saggerson, E. D. (1985). Formonal regulation of biosynthetic activities in white adipose tissue. In New Perspectives in Adipose Tissue: Structure, Function and Development, pp. 87-120 [A. Cryer and R. L. R. Van, editors]. London: Butterworths.

Schonk, D., Dijk, P. v., Riegmann, P., Trapman, J., Holm, C., Willcocks, T. C., Sillekens, P., Venrooij, W. V., Wimmer, E., Kessel, A. G. V., Ropers, H. H. \& Wieringa, B. (1990). Assignment of seven genes to distinct intervals on the midportion of human chromosome $19 \mathrm{q}$ surrounding the myotonic dystrophy gene region. Cytogenetics and Cell Genetics 54, 15-19. 
Scott, J. D. \& McCartney, S. (1994). Localization of A-kinase through anchoring proteins. Molecular Endocrinology 8, 5-11.

Soma, M., Mims, M. P., Chari, M. V., Rees, D. \& Morrisett, J. D. (1992). Triglyceride metabolism in 3T3-L1 cells. An in vivo ${ }^{13} \mathrm{C}$ NMR study. Journal of Biological Chemistry 267, 11168-11175.

Strålfors, P. \& Belfrage, P. (1983). Phosphorylation of hormone-sensitive lipase by cyclic AMP-dependent protein kinase. Journal of Biological Chemistry 258, 15146-15152.

Strålfors, P. \& Belfrage, P. (1985). Phosphorylation of hormone-sensitive lipase by cyclic GMP-dependent protein kinase. FEBS Letters 180, 280-284.

Strålfors, P., Olsson, H. \& Belfrage, P. (1987). Hormone-sensitive lipase. In The Enzymes, pp. 147-177 [P. D. Boyer and E. G. Krebs, editors]. New York: Academic Press.

Sztalryd, C. \& Kraemer, F. B. (1994a). Differences in hormone-sensitive lipase expression in white adipose tissue from various anatomic locations of the rat. Metabolism 43, 241-247.

Sztalryd, C. \& Kraemer, F. B. (1994b). Regulation of hormone-sensitive lipase during fasting. American Journal of Physiology 266, E179-E185.

Taira, M., Hockman, S. C., Calvo, J. C., Taira, M., Belfrage, P. \& Manganiello, V. C. (1993). Molecular cloning of the rat adipocyte hormone-sensitive cyclic GMP-inhibited cyclic nucleotide phosphodiesterase. Journal of Biological Chemistry 268, 18573-18579.

Thompson, M. P., Cooper, S. T., Parry, B. R. \& Tuckey, J. A. (1993). Increased expression of the mRNA for hormone-sensitive lipase in adipose tissue of cancer patients. Biochimica et Biophysica Acta 1180, $236-242$.

Vassaux, G., Gaillard, D., Ailhaud, G. \& Négrel, R. (1992). Prostacyclin is a specific effector of adipose cell differentiation. Its dual role as cAMP and $\mathrm{Ca}^{2+}$ elevating agent. Journal of Biological Chemistry 267, 11092-11097.

Vernon, R. G. \& Clegg, R. A. (1985). The metabolism of white adipose tissue in vivo and in vitro. In New Perspectives in Adipose Tissue: Structure, Function and Development, pp. 65-86 [A. Cryer and R. L. R. Van, editors]. London: Butterworths.

Warden, C. H., Davis, R. C., Yoon, M.-Y., Hui, D. Y., Svenson, K., Xia, Y.-R., Diep, A., He, K.-Y. \& Lusis, A. J. (1993). Chromosomal localization of lipolytic enzymes in the mouse: pancreatic lipase, colipase, hormone-sensitive lipase, hepatic lipase and carboxy ester lipase. Journal of Lipid Research 34, $1451-1455$.

Wesslau, C., Eriksson, J. W. \& Smith, U. (1993). Cellular cyclic AMP levels modulate insulin sensitivity and responsiveness. Evidence against a significant role of $\mathrm{Gi}$ in insulin signal transduction. Biochemical and Biophysical Research Communications 196, 287-293.

Wise, L. S. \& Jungas, R. L. (1978). Evidence for a dual mechanism of lipolysis activation by epinephrine in rat adipose tissue. Journal of Biological Chemistry 253, 2624-2627.

Wood, S. L., Emmison, N., Borthwick, A. C. \& Yeaman, S. J. (1993). The protein phosphatases responsible for dephosphorylation of hormone-sensitive lipase in isolated rat adipocytes. Biochemical Journal 295, 531-535.

Yeaman, S. J. (1990). Hormone-sensitive lipase - a multiplepurpose enzyme in lipid metabolism. Biochimica et Biophysica Acta 1052, 128-132. 